The Shanghai Green Gang 



\title{
The Shanghai Green Gang
}

Politics and Organized Crime, I919-1937

\author{
BRIAN G. MARTIN
}

University of California Press BERKELEY LOS ANGELES LONDON 
This book is a print-on-demand volume. It is manufactured using toner in place of ink. Type and images may be less sharp than the same material seen in traditionally printed University of California Press editions.

University of California Press

Berkeley and Los Angeles, California

University of California Press, Ltd.

London, England

(C) 1996 by

The Regents of the University of California

Library of Congress Cataloging-in-Publication Data

Martin, Brian G.

The Shanghai Green Gang : politics and organized crime, 1919-1937/ by Brian G. Martin.

p. $\mathrm{cm}$.

Includes bibliographical references.

ISBN 0.520.20114-0 (alk. paper)

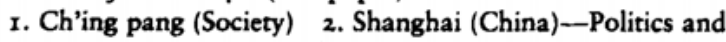
government. 3. Tu, Yüeh-sheng, 1888-195 I. I. Title.

DS $796 . S_{257} \mathrm{M}_{36} 1996$

$95 \mathrm{r}^{\prime} .132-\mathrm{dc20}$

Printed in the United States of America

The paper used in this publication meets the minimum requirements of ANSI/NISO Z39.48-1992 ( R 1997 )

( Permanence of paper. ) 
For Arja 
